\title{
An Analysis of Community Perceptions Towards Migration, Economic Development and Family Well-Being in Khyber Pakhtunkhwa Pakistan
}

\author{
A. Naz (Arab Naz)', Q Khan (Qaisar Khan)², T. Khan (Tariq Khan)³, \\ A. Gul (Ayesha Gul)4, F. Khan (Faisal Khan) ${ }^{5}$, \\ M. Humayun (Muhammad Humayun) ${ }^{5}$
}

1 Professor, Department of Sociology University of Malakand, Pakistan.

Original Article

2 Associate Professor, Department of English University of Malakand, Pakistan.

3 Assistant Professor, Department of English University of Malakand, Pakistan.

4 Assistant Professor SBKW University Quetta, Pakistan.

${ }_{5}$ Assistant Professor Management Studies University of Sawabi, Pakistan.

${ }^{6}$ Lecturer, Department of Law University of Malakand, Pakistan.

\section{E-mail address:}

arab_naz@yahoo.com

\section{Reprint address:}

Arab Naz

Department of Sociology

University of Malakand

Khyber Pakhtunkhwa

Pakistan

Source: Clinical Social Work and Health Intervention

Volume: 10

Issue: 3

Pages: $34-40$

Cited references: 12

\section{Reviewers:}

Daniel J. West, Jr.

University of Scranton, Department of Health Administration and Human Resources, USA

Clauss Muss

I-GAP Vienna, AT

\section{Keywords:}

Poverty. Remittances. Economic Development. Migration Family Income. Well-being.

\section{Publisher:}

International Society of Applied Preventive Medicine i-gap

CSWHI 2019; 10(2): 34 - 40; DOI 10.22359/cswhi_10_3_10 @ 2019 Clinical Social Work and Health Intervention 


\section{Abstract:}

The research study is a critical analysis that examines the perceptions of migrants towards economic development in the District Dir Lower Khyber Pakhtunkhwa Pakistan. The analysis has been made on both original field research as well as extensive review of literature to contextually prove how migration is affecting the economic progress of the society. Similarly, the literary debate is confounded through field data and primary data collected through in-depth interviews from 60 migrants' households purposively selected along with observation and focus group discussion. Overall, a qualitative research design is utilized and the narration and explanation of the various dimensions of migration and economic development has been performed from the field information with the support of secondary information. Results of the study conclude that migration is a major source of sending remittances that positively affect families, reduce poverty, increase income level, support family well-being and enhance the living standards of dependents.

\section{The Study Background}

The change that has been found in the last few years is the increase in the ratio of migratory advancement. Beside many restrictions, the migrating people continue to seek economic opportunities abroad (Alonso, 2011). The United Nations has estimated that for the year 2010, 214 million migrants made up $3 \%$ of the world population residing in countries other than their origin. However, it has been recorded from various studies that such a percentage seems very low compared to the overt and covert impact of migration i.e. the socio-cultural, economic and political as well as with respect to families left behind, and bring economic progress as well as being a great source of development (Haas, 2007a, Ellerman, 2005, Alonso, 2011).

Studies have clearly emphasized the economic issues and particularly the remittances which are mainly responsible for economic development, poverty reduction and well-being of those households (Ellerman (2005). Literature review and discussion conclude that migration for employment and labor is a major source of economic de- velopment in underdeveloped nations and such migration and remittances have impact on the reduction of poverty; allocation of income; disparities; exchange rates; is playing a pivotal role in individual and family wellbeing.

\section{The Study Rationale}

The current study is about people's perception with respect to migration and economic development that has been brought through remittances sent back by migrants to their recipient households. It is a fact that the nature and aspect of migration is dependent upon behavior of the migrants toward income decisions taken by migrants and their families (Reza, 2005). Migration of household members and their earnings improve the economic and social status of the family (Arif, 2004). Thus the current study looks into the perception of the migrant households regarding their remittances sent to their native homes and how such remittances increase the status of families in terms of poverty reduction, investment and family well-being. 


\section{Objectives in the context of the Study:}

Major objectives are:

1. To study the magnitude of people's perceptions regarding migration and poverty alleviation.

2. To know public perceptions regarding migration and household income and facilitation.

3. To judge the perception of people toward increases in investments and monetary benefits.

\section{Plan of Work and Procedural Methodology}

The nature of the study is qualitative based upon the interpretation, enumeration of data in the form of textual confirmation and explanation (Bogdan \& Biklen, 1982). However, field data as obtained and recorded is thus finalized to results and the pattern linked with both primary and secondary data for producing theory (Roney, 2000). The data gained through interviews, case studies etc. is analyzed in the form of narration, description as well as decimation with proper coding in a systematic manner (Wolcott, 1994). The field information has been obtained from 60 informants (in a survey during one month) in face to face conversation using an interview guide as a tool. Household selection was made through purposive sampling technique and a link has been established between the field data and theoretical stances of social and economic scientists.

\section{Major Research Findings And Discussion Over Findings On Migration, Remittances And Poverty Reduction}

Among the positive changes that migration might have brought in countries is the reduction of community poverty and especially of migrant families. The field data also support the available literature and most of the respondents were of the opinion that migration labor is one of the major sources of sending remittances to support families. Such remittances increase the standard of life of the people to a greater extent as supported by a majority of participants. One of the extracts from an interview reports that: "Previously, our family members have not had enough resources to live a standard living prevalent in the area. They were deprived of material goods and facilitation services for most of the available services. In other words, we were all in a kind of complex for being deprived and not of equal standing with community members......(R-S5).

Concerning poverty reduction and family assistance through migration, obtained information indicate that family assistance has enormously increased in families where one or more family member is out of the country for work. In such assistance, the demand for money, family expenses, purchasing power, and surplus money availability has been observed and supported by a major cohort of respondents. Concerning surplus money, a respondents enthused: "Yah; I have much more surplus i.e. in my bank account, loans given to people and even at home. I also have two cars, one tractor to work in my own fields and I am generous in supporting my family members for every occasion (including marriage, health, food, shelter, education, health, etc.). Surely, all this was not possible a decade ago..... (RE17)".

With regard to various forms of assistance, the respondents perceive that social assistance has been increased enormously to cover their basic needs with particular reference to women's poverty reduction and education of children of migrants. Parents have obtained maximum facilitation in the form of education, health and even recreation while a change has been found 
in facilitation in terms of household management; water utilization; fuel and gas consumption; clothes and ornamentation; expenses for marriage and other arrangements; access to health and education as well as markets etc..(R.J34)".

Similarly, the housing pattern and level of facilitation during house construction and decoration was also observed and analyzed and most of the people perceive that migrants are currently residing in their own houses, which to them previously was a dream. The majority of migrants have cement houses and even have purchased land for future purposes as well. The houses are linked with guest rooms or hujras for foreign guests with modern and well sophisticated facilities. Families have their own cars or other transportation facilities available whereas such facilitation was impossible before migration. As narrated by a person: "Yes of course, cemented house and to have my own house was really a dream for me and my children. I am thankful to Almighty Allah for giving me a house, will facilitated in all aspects. I am self-sufficient in transportation, land and many of the requirements of life. Indeed, this was impossible if I hadn't migrated abroad for work......(R-W11). The analysis and discussion thus extracted that poverty of the migrant families have been reduced to a maximum level and most of the families have sufficient facilities of life.

\section{Migration And Increase In Family Income}

Family members utilize their income for food items, health related issues, clothing, education of the young generation as well as saving for future activities. Most of the people perceive that the expenditures incurred through labor migration have significantly increased the expenses of households, particularly of women on their dressing, clothing and buying ornamentation and utensils.
Besides, an increase has been found in the amount of food expenses, buying clothes and even health and medication along-with children's education as stated by a respondent. "I can observe a major change in the pattern of life in my family. Comparatively, females are spending more on clothes, visiting families and buying ornamentation (gold) as they are in competition with neighboring relatives. The usual expenses of family are now in lacks as compared to a few years ago when our elders were spending hundreds on such expenses.... (R-T55).

Participants perceive that previously luxuries were rarer whereas after migration such focus has been intensified. Most people perceive that male members who are working abroad are specifically concerned with their children's education and mostly they want to send their children to private schools to attain quality education being more expensive as stated by a person: "I remember that the cooking of second type of food item was considered as luxury in my family, but today no such care is taken for second or third dishes and even fruits and cold drink with a meal is the usual pattern of services at lunch or dinner. Our children are preferring private schools on the demand of the parents and there is competition among family members for such schools (R-A-60)".

Information and its analysis thus conclude that the buying power and capabilities of the majority of family members have been increased to a major extent and further, such remittances had improved the housing expenses, purchasing power, and expenses on education as compared to houses where no such remittances are received.

\section{Migration, Remittances And Increasing Investments}

From the analysis, it is obvious that household services and purchasing power 
has been enormously increased and participants agreed upon the notion that income resources and their utilization has been increased and chances for investment are also increased manifold in the locality as narrated by a respondent. "I personally wonder how enormously investments on purchasing land, building markets, installing petrol pumps, opening shops etc. have been increased in the area. Lots offacilities i.e. educational institutions, health care centers, shopping malls, trade centers, and other daily life facilitation has been doubled or even manifold in the past five or six years (R-J28).

Most of the migrants are interested in initiating their own small scale businesses, search for jobs, construction of markets and plazas, and many times people are open to invest money in construction of housing schemes. Data shows that people of the migrant families and households have enhanced their productive capacity through investments while an increase has been observed in production of material goods in such families as noted. "I am investing more on constructing market and buying land for establishing centers. Today, I am more stable and richer than my brothers and family members by owning multiple markets and centers which are income generation sources for me and my family...(R-S21).

Analysis also shows that most migrants are interested in purchasing agricultural land or even investing to irrigation and agricultural productivity. Besides, migrants families have more chances for increase in trade and other economic activities with respect to the non-migrants families in the area and such people have more control over valuable goods and information about production, demand and supply items, policies and prevailing conditions in the country or abroad.

\section{Migration And Household Welfare}

Analyzing the field information with respect to migration and family wellbeing, most of the participants are of the opinion that the majority of the migrant families are well facilitated with respect to availability of food, access to health facilities, access to education and other basic needs. Families of migrants have more concern regarding family well-being, education, health, and future planning with regard to family and young ones as narrated by a participant. "I have almost spent more than 25 years outside my homeland and I have earned millions of rupees but I wish that my children shall get better education to support themselves and my labor shall bring some fruit in future ... (R-D30).

Similarly, most of the respondents were of the opinion that migration has positive impact with many factors responsible for education and its development including sending children to school, decreases in drop-out, and mostly, the importance of education in the area. Parents in such families are more stressing upon academic performance and grade achievements and are more focusing on children's study hours and utilization of time. Analysis confirms that most of people have an improved health conditions whereas the migrant households found open access towards improved health-care facilities i.e. doctors, hospitals, daycare centers and even to medical practitioners. Further, migration and remittances have improved children's overall health condition because such families have awareness with respect to healthy diets, food, and health and other services and the utilization of such services have positive health outcomes as narrated by a field respondent. "Today we are all aware of our children's health, food requirements, and even to provide them all the health care as well. I myself took my children to a special- 
ist doctor and I even spend a lot of money on it. Sometime, even for a very little health issue, we visit the best doctor in the area or in the country. .(R-U59).

Extracted from the analysis that families and households left behind are getting more facilitation as compared to non-migrant families in terms of food, health, clothing, education and even recreation. The majority of people view that migration and remittances are a compulsory aspect of family well-being and the remittances have improved welfare of children, aged people and even girls and women in the area.

\section{Summary and Conclusion}

Analyses indicate that a major chunk of migrants living outside their own country and sending money back have observed a shift in their social and economic as well as personal relationship to the rest of society. In an analysis of the poverty component, migration has been the major contributor to reduce poverty as well as in many cases have increase family incomes; expenses on buying food items, health facilitation, clothes and other things have increased enormously and have thus changed the life style of the migrants to a greater extent. Migration has brought many changes in the family structure; role of family members; even in the decision-making process of the family. Extra money has improved the life expectancy and then has increased the purchasing power of the family to a maximum extent to have markets, land, education, recreation facilities and even extra cash in the banks accounts. Similarly, there has been an enormous increase due to migration in the form and services related to health, family and educational facilitation to the larger extent. It is thus concluded that that migration and remittances are pivotal in family economic as well as social development of the area.

\section{Policy Recommendations And Future Research Indicators}

It is recommended that migration has damaged the moral and value system; absence of social control towards kids and their activities; habit of extravagancy has been created; issues of psychological nature; care for children has been reduced which needs attention of the policy makers.

\section{References:}

1. ALONSO J A (2011) International Migration and Development: A review in light of the crisis. Journal of Economic and Social Affairs, CDP Background Paper No. 11(E) ST/ESA/2011/CDP/11(E).

2. ALPER A M, NEYAPTI B (2006) Determinants of workers remittances: Turkish evidence from and Children Who Migrate with a Parent. Unpublished Paper.

3. ARIF G M (2004) Effects of overseas migration on household consumption, education, health and labour supply in Pakistan, In Hisaya Oda (Ed.), International Labour Migration From South Asia, Institute of Developing Economies and Japan External Trade Organization, Chiba, Japan.

4. BOGDAN R, BIKLEN S (1982) Qualitative research for education: An introduction to theory and methods. Boston, MA: Allyn and Bacon.

5. BRYANT J (2005) Children of International Migrants in Indonesia, Thailand, and the Philippines: A Review of Evidence and Policies. Innocenti Working Paper. InnocentiResearch Centre. UNICEF.

6. CAMACHO Z G, KATTYA HERNANDEZ B (2007) Children and Migration in Ecuador: Situation Diagnostic. Centre for Social Planning and Research. UNICEF.

7. CORTES R (2007) Children and Women Left Behind in Labor Sending Countries: An Appraisal of Social Risks, Global Report on Migration and Children. Report to UNICEF. 
8. ELLERMAN D (2005) Labour migration: A developmental path or a low-level trap? Development in Practice, 155: 617 - 630.

9. GOULD D (1994) Immigrants Links to the Home Country: Empirical Implications for U.S. - Bilateral Trade Flows, Review of Economics and Statistics, 762: 302-316.

10. HODDINOTT J (1994) A Model of Migration and Remittances Applied to Western Kenya, Oxford Economic Papers, 46 (3), July: 459-476.
11. RAMIREZ C, DOMINGUEZ M G, MORAIS J M (2005) Crossing Borders: Remittances, Gender and Development, pp. 32-33. INSTRAW Working Paper. Santo Domingo: United Nations International Research and Training Institute for the Advancement of Women.

13. RONEY K (2000). Characteristics of effective middle level teachers: A case study of principal, teacher, and students perspectives. (Unpublished doctoral dissertation). Temple University, Philadelphia. 